\title{
The Relationship between Critical Thinking Disposition and Locus of Control in Pre-Service Teachers
}

\author{
Aytunga Oğuz ${ }^{1}$, Hakan Sariçam² \\ ${ }^{1}$ Department of Educational Curriculum and Instruction, Faculty of Education, Dumlupinar University, Kütahya, 43100, \\ Turkey \\ ${ }^{2}$ Department of Psychological Counseling and Guidance, Faculty of Education, Dumlupinar University, Kütahya, 43100, \\ Turkey \\ Correspondence: Hakan Sariçam, Department of Psychological Counseling and Guidance, Faculty of Education, \\ Dumlupinar University, Kütahya, 43100, Turkey.
}

Received: November 11, 2015 Accepted: November 23, $2015 \quad$ Online Published: December 7, 2015

doi:10.11114/jets.v4i2.1196

URL: http://dx.doi.org/10.11114/jets.v4i2.1196

\begin{abstract}
The aim of the current research study was to examine the link between critical thinking dispositions and locus of control in pre-service teachers. The participants of this study were selected via easily accessible sampling technique. The participants consist of 347 pre-service teachers (203 female, 144 male) in Kütahya, Turkey. The Rotter Internal-External Locus of Control Scale and Critical Thinking Dispositions Scale aided in data collection. Once the data was transferred to an electronic environment and did not show a normal distribution in terms of gender and grade variables, so Mann Whitney-U test was used in order to comparing analysis and Spearman's correlation analysis was used for examining the level of relationship between variables. According to comparison analysis, the external locus of control and critical thinking dispositions differentiated with respect to gender and grade. In correlational analysis and regression analysis, there was a negative relationship between external locus of control and critical thinking dispositions. Results were discussed by the light of the related previous studies.
\end{abstract}

Keywords: critical thinking, critical thinking disposition, locus of control, pre-service teachers

\section{Introduction}

\subsection{Current Study}

This goal of the research study is to investigate a relationship between critical thinking dispositions and locus of control in pre-service teachers. In the information society, in order for individuals to gain, produce, and interpret information after obtaining it, they are required to develop thinking skills, especially critical thinking skills Facione, 1990). Rose (1978) indicates that when compared to teachers who have external locus of control, teachers who have internal locus of control engage more actively in teaching activities; they control their students less but more effectively. Teachers who have an internal locus of control have students who take more responsibility to demonstrate their performances. Accordingly, teachers who have critical thinking dispositions and internal locus of control will possess the ability to created active learning environments when they become teachers in the future (Saracaloğlu \& Yılmaz, 2011). In teacher training, several studies exist displaying an investigation about teachers and pre-service teachers' critical thinking skills dispositions and locus of control in terms of different variables such as gender, age, grade, education levels, and etc. (Bakır, 2015; Buluş, 2011; Bostic, 2010; Dunn, Rakes, \& Rakes, 2014; Fagbohungbe \& Jayeoba, 2012; Loghmani, 2010; Vierra, 2014; Wood, Saylor, \& Cohen, 2009).

Moreover there is a few research studies (e.g., Bahadir, Cartel, \& Turan, 2014; Flor et al., 2013; Ishiyama et al., 1999) about the relationship between the locus of control and critical thinking dispositions. However as far as we know, there is no studies about the link between locus of control and critical thinking dispositions in pre-service teachers. Therefore, in the research study, the critical thinking dispositions of pre-service teachers have been dealt within the scope of its relationship to locus of control was anticipated.

\subsection{Critical Thinking Dispositions}

As Facione (1990) states, critical thinking is a substantial requirement for individuals of the information age. In this 
context, it is emphasized to develop students' high-level thinking skills, such as their critical thinking skills by designing constructivist curricula. Constructivist learning environments are organized for students to take the responsibility for their own learning, become active learners, and endeavor to enhance their own individual characteristics (Cır1k, Colak, \& Kaya, 2015; Marlowe \& Page, 2005; Tuncel \& Bahtiyar, 2015). Critical thinking is one of the skills individuals might possess to develop lifelong active learning roles (Gibby, 2013). Developing critical thinking skills is also one of the requirements for individuals to be active members of a democratic society (Dam \& Volman, 2004; Lai, 2011).

Individuals who are going to create and maintain a democratic society need to possess critical thinking skills (Lai, 2011; Zyngier, 2012). In a democratic society, when individuals develop critical thinking skills, they can solve the social problems they encounter. For example, critical thinking skills enhance power relations (Zyngier, 2012). Critical thinking and problem solving are cognitive processes related to each other (Laxman, 2010; Shah, 2010; Tümkaya, Aybek, \& Aldağ, 2009). When considered from these aspects, individuals' developing critical thinking skills play an important role in individuals' lives and social life (WHO, 2001). Hence, scientists in higher education emphasize that the aim of education must be to bring individuals in critical thinking skills (Richmond, 2007). One of the aims of critical thinking is to develop students' critical perspective by providing to challenge information, check over faults and mistakes (Slavin, 2012).

According to Paul and Elder (2012), "Critical thinking is the intellectually disciplined process of actively and skillfully conceptualizing, applying, analyzing, synthesizing, and/or evaluating information gathered from, or generated by, observation, experience, reflection, reasoning, or communication, as a guide to belief and action." Individuals having the ability to think critically should possess some characteristics (Zhang, 2003). For example, according to Ennis (1996), critical thinkers have the abilities to elucidate, to explore and reconsider well the basis for an idea, to judge wisely from the basis, to creatively estimate and combine, and to do these things with dispatch, sensitivity, and bombastic skill. In curricula, to achieve critical thinking skills, students must develop cognitive skills such as analyzing, making connections, making inferences and evaluation, critical thinking dispositions and habits such as disputing, searching for reasons and evidences and open-mindedness (Elder \& Paul, 2008).

However, critical thinking skills, dispositions, and habits cannot develop automatically and randomly. Critical thinking is a cognitive process achieved by using active methods by means of training (Bloom, 1976; Thompson, 2011). Kaasboll (1998) emphasizes that it is necessary to follow the principles such as student participation, teacher-student interaction, inductive teaching and integrating the disciplines in the training process in which critical thinking and problem solving skills. Therefore, teachers should encourage their students to discuss, do logical analyses and investigate their own thinking processes in their courses (Cohen, 1993). Above opinions indicate that teachers should organize a democratic learning environment in which students can talk and discuss freely in the classrooms (Morrison, 2008). In such an environment students should be respected, provided to reveal their ideas freely and they should not be insulted and compared to each other (Braa \& Callero, 2006). Briefly stating, not only how a learning environment is organized, but also teacher behaviors in this environment can have an influence on the development of critical thinking skills (Marina, \& Halpern, 2011; Varga, 2011; Walker, 2004).

In order for students to develop critical thinking skills and dispositions, they should undoubtedly be encouraged by their teachers (Winch, 2006). Teachers who can support their students about critical thinking should have developed critical thinking skills and dispositions in the first place. That's why pre-service teachers should be given a chance to develop critical thinking skills and dispositions. It is documented in the literature that as the individuals' educational and informational level increases, they approach the concept of critical thinking more broadly and scientifically, the increase in their educational and informational level affects the development of their critical thinking skills and dispositions positively and there is a positive relationship between critical thinking and achievement (Abrami et al., 2008; Bessick, 2008; Elliott, 1999; Jenkins 1998; Kaasboll, 1998; Ruff, 2005; Vierra, 2014). We conducted current research study in the context of pre-service teachers' critical thinking dispositions.

The results of the previous studies indicated that critical thinking dispositions relate to critical thinking skills and the socioeconomic status of families (Cheung et al., 2001; Facione, Facione \& Carol, 1994). Besides, critical thinking has a significant influence on divesting from mistakes or minimizing the number of them, increasing academic performance and training on critical thinking enhances the critical thinking dispositions of students (Bessick, 2008; Vierra, 2014). Furthermore, thinking styles of students contribute to their critical thinking dispositions (Zhang, 2003). Facione et al. (1995) stressed that critical thinking disposition is a significant predictor of psychological health and well-being. Hence, determining the critical thinking dispositions of pre-service teachers has a great importance.

\subsection{Locus of Control}

Another one of the pre-service teachers' personal characteristics is locus of control (Buluş, 2011). According to Rotter 
(2006), individuals could believe the outcomes obtained from either reveal an external locus of control or reveal an internal locus of control (Schunk, 2012). Marks (1998) explains "individuals with an internal locus of control experience reinforcements of value as more meaningful or influential to them because they believe that they have control over reinforcements; to increase or decrease the reinforcement, they change their behavior". Individuals who possess internal locus of control believe their achievements and failures result from their own efforts and abilities; whereas individuals with external locus of control regard their chance or difficulty of a work situation or others' behaviors as the reasons for their success and failures (Sarıçam, 2014). Internal and external factors have a role in the success students gained from an examination (Sarıçam, 2015; Sarıçam et al., 2012). An individual might have internal locus of control in a field while maintaining an external locus of control in another field (Slavin, 2012). Students who have internal locus of control succeed with synthesizing information, correlating, solving a problem, researching, and testing their individual information and skills (Konan, 2013). On the other hand, students with external locus of control need their teachers' support Miller, 2005). And also, they are more successful in repetitive activities and tasks requiring social interaction Dabbagh, 2007). According to Darshani (2014), the perception about internal locus of control is a positive personal characteristic. Further emphasis pertains to encouraging students to have internal locus of control instead of external locus of control (Sarıçam, 2015; Sarıçam et al., 2012; Shepherd et al., 2006).

Antecedent studies about higher education students' locus of control concluded that problems, aggression, self-acceptance, behavior of suspense, self-respect, level of loneliness, teaching strategies, and different variables such as sex, age, and etc. (Abouserie, 1994; Carden, Bryant, \& Moss, 2004; Ferrari, Parker, \& Ware, 1992; Grimes, Millea, \& Woodruff, 2004; Ishiyama, McClure, Hart, \& Amico, 1999; Tong, 2001; Wood, Saylor, \& Cohen, 2009; Zainuddin \& Taluja, 1990). Additionally, it can be indicated that the relationship between locus of control and achievement is the mostly investigated one among the studies and it is asserted that locus of control predicted achievement at a high level (Bostic, 2010; Carden, Bryant, \& Moss, 2004). Based on above mentioned studies we can say, teachers have important responsibilities in maintaining the academic achievement of students, determining the locus of control and organizing learning environments.

The characteristics of individuals having internal locus of control can be considered to match up with the characteristics of individuals who have developed critical thinking skills and dispositions. Saracaloğlu and Yılmaz (2011) notice that skills such as searching for reasons, evaluating the reasons correctly and re-questioning the reasons before believing them are common characteristics for both critical thinkers and individuals with internal locus of control. According to Attribution Theory, attributions affect beliefs, emotions and behaviors (Schunk, 2012). Researchers remark that critical thinking skills and locus of control are related to each other (Biggs, 1985; Çırakoğlu, 2006; Çırakoğlu \& Tezer, 2010; Derelioğlu, 2004; Flor et al., 2013; Ishiyama et al., 1999; Rose et al., 1996; Saracaloğlu \& Yılmaz, 2011). However, there is a considerable research gap in this area except for a few research studies focusing on the relationship between the terms of critical thinking dispositions and locus of control (e.g., Bahadir, Cartel, \& Turan, 2014). Therefore in current research study, we analyze pre-service teachers' critical thinking dispositions and locus of control.

Discuss the relevant related literature, but do not feel compelled to include an exhaustive historical account. Assume that the reader is knowledgeable about the basic problem and does not require a complete accounting of its history. A scholarly description of earlier work in the introduction provides a summary of the most recent directly related work and recognizes the priority of the work of others. Citation of and specific credit to relevant earlier works are signs of scientific and scholarly responsibility and are essential for the growth of a cumulative science. In the description of relevant scholarship, also inform readers whether other aspects of this study have been reported on previously and how the current use of the evidence differs from earlier uses. At the same time, cite and reference only works pertinent to the specific issue and not those that are of only tangential or general significance. When summarizing earlier works, avoid nonessential details; instead, emphasize pertinent findings, relevant methodological issues, and major conclusions. Refer the reader to general surveys or research syntheses of the topic if they are available. Demonstrate the logical continuity between previous and present work. Develop the problem with enough breadth and clarity to make it generally understood by as wide a professional audience as possible (Beck \& Sales, 2001). Do not let the goal of brevity lead you to write a statement intelligible only to the specialist.

\subsection{Aim of the Study}

The aim of this study is to analyze pre-service teachers' critical thinking dispositions and locus of control in terms of different variables and determine the relationship between pre-service teachers' critical thinking dispositions and locus of control. In accordance with this general aim, we asserted below hypotheses:

1. The external locus of control level of female pre-service teachers will be significantly higher than males.

2. The critical thinking dispositions of male pre-service teachers will be significantly higher than females.

3. There won't be a significant difference in the arithmetic means of pre-service teachers' external locus of control in 
terms of their grades.

4. $4^{\text {th }}$ grade pre-service teachers' critical thinking dispositions levels will be significantly higher than $1^{\text {th }}$ grade pre-service teachers' critical thinking dispositions levels.

5. There will be a relationship between pre-service teachers' critical thinking dispositions and internal locus of control.

6. External locus of control will be an important predictor for critical thinking dispositions.

\section{Method}

\subsection{Participants}

The participants of this study are selected with easily accessible sampling technique and the participants consist of 347 pre-service teachers (203 female, 144 male) studying at Dumlupinar University, Faculty of Education for the 20142015 academic year. The ages of the participants varied between 17 and 24 and the average age was 20.42. Moreover, 188 of pre-service teachers were $1^{\text {th }}$ year students whereas 159 of them were seniors.

\subsection{Instruments}

Rotter Internal-External Locus of Control Scale: Internal-External Locus of Control Scale, developed by Rotter (1966) was applied in this study to analyze the position of individuals' generalized control expectations on internal-external dimensions and to evaluate the general expectation or belief individuals have such as that the reinforces are under the control of internal or external forces (luck, destiny etc.). The scale comprises 23 items and each item consists of two statements. In the other questions namely $2,6,7,9,16,17,18,20,21,23,25$ and 29, option "a" stands for 1 point whereas option "b" means 0 point; items $3,4,5,10,11,13,15,22,26$ and 28 , "b" refer to 1 point and option "a" means 0 point. Total score of the scale range from 0 and 23 points. If a participant gets a high score from this scale, it means that there is an increase in external locus of control. The scale was adapted into Turkish by Dağ $(1991 ; 2002)$. According to Dağ (1991)'s validity and reliability study which was conducted on students, test- retest reliability coefficients of the scale was calculated as $\mathrm{r}=.83(\mathrm{p}<.01, \mathrm{sd}=98)$. Moreover, KR-20 reliability coefficient of the scale was calculated as .68 whereas Cronbach's alpha internal consistency coefficient was found as .70 . The validity and reliability study of the scale with pre-service teachers was conducted by Küçükkaragöz, Akay and Canbulat (2013) and as a result a structure having 8 sub-dimensions whose eigenvalues are above "1" was obtained. Cronbach's alpha internal consistency coefficient of the scale was calculated as .74. The lowest attained Cronbach's alpha internal consistency coefficient of the scale was found to be .72 by removing any item from the scale. Test- retest reliability study of the study was conducted with 61 pre-service teachers 3 weeks after the first application and in this second application correlation coefficient of the scale was calculated as $r=.69$.

Critical Thinking Dispositions Scale: Critical Thinking Dispositions Scale was developed by Sosu (2013) and it consists of 11 items and 2 sub-dimensions (critical openness and reflective scepticism). The scale in which self-evaluation of participants is intended, is a sample of 5-point Likert scale whose grades are named as "1-Totally Disagree" and "5-Totally Agree". Turkish adaption of the scale was conducted by Akın, Hamedoğlu, Sarıçam et al. (2013). As a result of confirmatory factor analysis which was applied on the data obtained from applying the scale to 432 students studying in the department of Classroom Teaching in the Faculty of Education to maintain the construct validity of the scale, a model with 11 items and 2 sub-dimensions which have fit indices calculated as NFI= .92, CFI= .93, IFI $=.93$, RFI $=.89$, $\mathrm{SRMR}=.026$. In another similar validity study, a positive relationship $r=.29$ was found between Critical Thinking Dispositions Scale and Self-Criticism Scale. Cronbach's alpha reliability coefficient was calculated as .97 for the whole scale, it was also found as .95 for critical openness sub-dimension, and .96 for reflective scepticism sub-dimension. On the other hand, test- retest reliability coefficient of the scale was calculated as .62. The improved form of the items' total correlation coefficients vary from .71 to .94 and also $27 \%$ of sub group and super group levels of the scale show a significant difference.

\subsection{Procedures}

At this stage, Rotter Internal-External Locus of Control Scale, Critical Thinking Dispositions Scale and Personal Information Form are applied to 347 participants by one of the researchers of this study personally. Before the applications, it was expressed to pre-service teachers that those forms would be used with academic purposes and also the general aim of the study was explained. After that volunteer students were given 20 minutes to fill in the forms and then distributed forms were collected. As the data transferred to electronic environment did not show a normal distribution in terms of gender and grade variables, one of the non-parametric tests, Mann Whitney-U test was applied and in order to determine the level of relationship between variables, Spearman's correlation analysis was used. Moreover, in order to determine the explanatory role of external locus of control on critical thinking dispositions, 34 of data which spoiled the normal distribution of the data were disposed and simple linear regression analysis was applied. The significance level was considered to be $\mathrm{p}<.01$. 


\section{Results}

\subsection{External Locus of Control and Critical Thinking Dispositions in terms of Gender}

In order to determine whether the participants' external locus of control and critical thinking dispositions show a significant difference or not Mann Whitney-U test was applied and findings are given Table 1.

Table 1. Mann Whitney-U test results of pre-service teachers' external locus of control and critical thinking dispositions' in terms of gender

\begin{tabular}{lcccccc}
\hline \multirow{2}{*}{ Variable } & \multicolumn{2}{c}{ Female $(\mathrm{N}=203)$} & \multicolumn{2}{c}{ Male $(\mathrm{N}=144)$} & $\mathrm{U}$ & $\mathrm{p}$ \\
\cline { 2 - 5 } & $\mathrm{X}$ & $\mathrm{SD}$ & $\mathrm{X}$ & $\mathrm{SD}$ & & \\
\hline $\begin{array}{l}\text { Locus of } \\
\text { control }\end{array}$ & 14.85 & 2.78 & 10.96 & 3.11 & $4870.00^{* * *}$ & .00 \\
$\begin{array}{l}\text { Critical } \\
\text { thinking }\end{array}$ & 27.61 & 7.40 & 31.99 & 8.17 & $10172.00^{* * *}$ & .00 \\
$* * \mathrm{p}<.00$ & & & & & &
\end{tabular}

When Table 1 is investigated, it can be stated that the external locus of control means of female pre-service teachers $(\overline{\mathrm{X}}=14.85)$ was higher than male pre-service teachers $(\overline{\mathrm{X}}=10.96)$; and this difference was statistically significant $(\mathrm{U}=4870.00, \mathrm{p}<.01)$. Furthermore, the means of females' critical thinking dispositions $(\overline{\mathrm{X}}=27.61)$ were lower when compared to males' critical thinking dispositions $(\overline{\mathrm{X}}=31.99)$; and this difference was also statistically significant $(\mathrm{U}=10172.00, \mathrm{p}<.01)$.

\subsection{External Locus of Control and Critical Thinking Dispositions in Terms of Grade}

In order to determine whether there is a significant difference in the arithmetic means of participants' external locus of control and critical thinking dispositions or not Mann Whitney-U test was applied and results are given Table 2.

Table 2. Mann Whitney-U test results of pre-service teachers' external locus of control and critical thinking dispositions' in terms of grade

\begin{tabular}{lcccccc}
\hline \multirow{2}{*}{ Variable } & \multicolumn{2}{c}{ 1st grade $(\mathrm{N}=188)$} & \multicolumn{2}{c}{ 4th grade $(\mathrm{N}=159)$} & \multirow{2}{*}{$\mathrm{U}$} & $\mathrm{p}$ \\
\cline { 2 - 5 } & $\mathrm{X}$ & $\mathrm{SD}$ & $\mathrm{X}$ & $\mathrm{SD}$ & & \\
\hline $\begin{array}{l}\text { Locus of } \\
\text { control }\end{array}$ & 13.37 & 3.42 & 13.07 & 3.57 & 13960.5 & .29 \\
$\begin{array}{l}\text { Critical } \\
\text { thinking }\end{array}$ & 27.78 & 7.34 & 31.36 & 8.36 & $11489.00 * *$ & .00 \\
$* * \mathrm{p}<.00$ & & & & & & \\
\hline
\end{tabular}

When Table 2 is analyzed, it can be remarked that the external locus of control means of $1^{\text {st }}$ grade pre-service teachers $(\overline{\mathrm{X}}=13.37)$ was higher than $4^{\text {th }}$ grade pre-service teachers $(\overline{\mathrm{X}}=13.07)$; and this difference was not statistically significant $(\mathrm{U}=13960.5, \mathrm{p}>.01)$. Moreover, the arithmetic means of $1^{\text {st }}$ grade pre-service teachers' critical thinking dispositions ( $\overline{\mathrm{X}}=27.78)$, were lower when compared to $4^{\text {th }}$ grade pre-service teachers $(\overline{\mathrm{X}}=31.36)$; and this difference was found to be statistically significant $(\mathrm{U}=11489.00, \mathrm{p}<.01)$.

\subsection{Correlation Analysis}

So as to determine the relationship between external locus of control and critical thinking dispositions Spearman's correlation analysis was applied and the results are demonstrated in Table 3.

Table 3. Explanatory values, Cronbach's alpha and correlation coefficients of the relationship between external locus of control and critical thinking dispositions

\begin{tabular}{lll}
\hline Variables & 1 & 2 \\
\hline 1.External locus of control & 1 & \\
2. Critical thinking dispositions & $-.44 * *$ & 1 \\
\hline Means & 13.23 & 29.43 \\
Standart deviation & 3.49 & 8.01 \\
Cronbach's $\alpha$ & .73 & .84 \\
\cline { 2 - 2 }$<.01$ & &
\end{tabular}

When Table 3 is investigated, it can be indicated that there is a negative relationship between pre-service teachers' external locus of control and critical thinking dispositions in the significance level of $\mathrm{p}<.01$. In other words, as the external locus of control level increases the level of critical thinking dispositions decreases or the level of critical thinking dispositions shows an increase while the internal locus of control level increases.

\subsection{Regression Analysis}

For the last hypothesis of this study, simple linear regression analysis was applied; critical thinking dispositions were 
regarded as dependent variables whereas external locus of control was considered to be independent variable. The results are demonstrated in Table 4.

Table 4. Simple Linear Regression Analysis for Critical Thinking Dispositions

\begin{tabular}{lllcccc}
\hline $\mathbf{V}$ & $\mathbf{R}$ & $\mathbf{R}^{2}$ & $\mathbf{F}$ & $\mathbf{B}$ & $\mathbf{t}$ & $\mathbf{p}$ \\
\hline MA & .46 & .21 & $91.52^{* *}$ & -.46 & 9.57 & .00 \\
\hline
\end{tabular}

Dependent variable: Critical thinking dispositions (CTD)

Independent variable: External locus of control (ELC)

According to Table 4, regression model can be identified as statistically significant and also external locus of control is a negative explanatory for critical thinking dispositions. External locus of control explains $21 \%$ of the total variation of critical thinking dispositions. Depending on this data, it can be stated that locus of control is an important predictor for critical thinking skills.

\section{Discussion and Recommendations}

The primary aim of this study was to determine the relationship between pre-service teachers' locus of control and critical thinking dispositions. Moreover, it was also intended to test whether the arithmetic means of locus of control and critical thinking dispositions differs significantly in terms of gender and grade variables.

According to the first hypothesis of the study, pre-service teachers' locus of control was expected to significantly differ in terms of gender. The finding obtained about the first hypothesis was that female pre-service teachers' arithmetic means of external locus of control was higher when compared to males whereas the male pre-service teachers' arithmetic means of internal locus of control was found to be higher than females. There are many studies in literature Fagbohungbe \& Jayeoba, 2012; Gašić-Pavišić, Joksimović, \& Janjetović, 2006; İslambay, 2014; Özen Kutanis, Mesci, \& Övdür, 2011; Sherman, Higgs, \& Williams, 1997; Stocks, April, \& Lynton, 2012; Türker \& İnel, 2012) which conducted that males have more internal locus of control than females while females have more external locus of control when compared to males. These findings have parallels with the findings of this study. The reason why females have more external locus of control might be because of the fact that the social desirability level of females are higher than males (Novicki, 1973; Sherman, Higgs, \& Williams, 1997) and also it might be on the grounds of cultural structure (McLaughlin \& Saccuzzo, 1997) or gender roles (Kleiber \& Hemmer, 1981) of the societies females live on. As a result it can be clearly stated that the first hypothesis of the study was confirmed.

In the following hypothesis of the study, it was expected that the critical thinking dispositions of female pre-service teachers would be lower when compared to males. According to the data obtained from this study, the critical thinking dispositions of male pre-service teachers were found to be higher than females. However, in literature there are some studies not supporting this finding of the study. For example, Çakmak Güleç (2010) asserted in her study that the critical thinking dispositions of females were statistically higher when compared to males. Similarly, Facione et al. (1995) obtained the same finding in their study. On the other hand, in Leach (2011)'s extensive study, it was concluded that the critical thinking dispositions of males studying in the faculties of Arts and Sciences (M=197, F=291), Business and Technology ( $M=259, F=134)$, Clinical and Rehabilitative Health Sciences ( $M=9, F=78)$, Continuing Studies ( $M=29$, $\mathrm{F}=29)$, Education $(\mathrm{M}=70, \mathrm{~F}=207)$, Nursing $(\mathrm{M}=14, \mathrm{~F}=138)$, Public Health $(\mathrm{M}=16, \mathrm{~F}=31)$ were higher when compared to females. In another similar study conducted by Taş and Erden (2007), it was determined that the critical thinking dispositions of female students studying in different faculties were quite lower than male students. Carrillo and Benítez (2004) expressed that the difference between critical thinking dispositions of females and males might be aroused as a result of the socio-cultural environments individuals live or their backgrounds and experiences (educational background, family structure, social class etc.). The recent studies conducted in the last years might be predicated to support the findings of this study. Based on these findings, it can be concluded that the second hypothesis of this study was confirmed.

In the third hypothesis of the study, it was asserted that there would not a statistically significant difference in the arithmetic means of pre-service teachers' external locus of control in terms of grade variable. According to the findings obtained from this study, there was not observed a significant difference in pre-service teachers' arithmetic means of locus of control between 1st grade students and senior students. In the study conducted by Munir and Sajid (2010) focusing on academic staff, it was asserted that young academicians have more external locus of control whereas the elder academicians have more internal locus of control when compared to younger academicians. Likewise, in the study of Özen Kutanis, Mesci, and Övdür (2011) it was concluded that as the university students' levels increased, their internal locus of control increased, as well. Furthermore, in the study conducted by Stocks, April, and Lynton (2012) in South Africa, it was remarked that the participants' ages and their internal locus of control were in direct proportion with each other, which means that together with the participants' ages their locus of control increased. It can be stated 
that the findings of these studies are in accordance with the findings of this study. In the light of the related literature, it can be asserted that the third hypothesis of the study was confirmed.

According to the fourth hypothesis of the study, it was expected that the critical thinking dispositions of 1st grade students would be significantly lower than those of the 4th grade students. The finding obtained from this study indicated that the arithmetic means of critical thinking dispositions of senior students were significantly higher when compared to 1st grade students. However, when the literature was investigated, it was found that there were many studies concluding that age is not a significant predictor for critical thinking dispositions (Rodriquez, 2000; Rudd, Baker, \& Hoover, 2000; Thompson et al., 2003) whereas there are many studies which assert the contrary of those studies. For instance, it was concluded in the study of Doğanay, Taş and Erden (2007) that there was a significant difference in the means of participants' critical thinking skills in terms of age. Moreover, Faciona et al. (1999) determined in their study that the critical thinking dispositions of senior university students were higher when compared to 1st grade students. In addition, it was asserted in the study conducted by Dunn, Rakes and Rakes (2014) that age was a significant predictor for critical thinking dispositions and as the age of participants increased, their critical thinking levels also increased. These studies support the finding of this present study. From this point of view, it can be remarked that the fourth hypothesis of the study was confirmed.

In the fifth hypothesis of the study, it was asserted that there was a relationship between the locus of control and critical thinking dispositions of pre-service teachers. Moreover, according to the sixth hypothesis of the study, it was expressed that external locus of control was an important predictor for critical thinking dispositions. According to the findings, it was determined that when the arithmetic means of external locus of control increased, critical thinking dispositions decreased. In addition, it was concluded that external locus of control explained more than $20 \%$ of the total variance of critical thinking dispositions. Flor et al. (2013) also stated in their studies that there was a negative relationship between critical thinking skills and external locus of control. Moreover, Saracaloğlu and Yilmaz (2011) found a positive relationship between the attitudes of participants towards critical thinking and their internal locus of control. Similarly, in their studies Ewen (2001) and Loghmani (2010) came to the conclusion that internal locus of control was a significant predictor for critical thinking. It can be remarked that all these studies support the findings of this study. In accordance with these findings, it can be stated that the fifth and sixth hypotheses of the study were confirmed.

There seems to be some limitations in the study. First of all, this research was conducted in a city of Turkey. Most of the students studying in this city live in the west part of Turkey. That's why similar studies should be conducted with students studying in the universities placed in the east part of the country by extending the participants. Secondly, 1st grade students and senior university students were included in this study. 2nd grade and 3rd grade university students can be implicated in other similar studies. Lastly, the study was conducted with university students who are also pre-service teachers. In the other similar studies, teachers can also be included as participants and it can be investigated whether there is a difference between these two groups; teachers and pre-service teachers.

This research will probably have substantial influences for further studies and applications. It was concluded in this study that especially age and gender are significantly explanatory both for critical thinking dispositions and locus of control. In the previous studies, similar findings were encountered and it can be regarded as an important result that even though many years have passed, these differences have emerged in the contemporary world where gender equality is argued and also the young individuals are more externally focused who can reach information easily in the digital age. It can also be identified to be quite important that there is a relationship between critical thinking dispositions and internal locus of control because it is asserted that individuals are primarily required to have critical thinking dispositions in order to think critically. In many countries, the educational systems are intended to bring critical thinking skills in students. However, it is necessary to motivate individuals to think critically. So as to come through with such a result, individuals are required to have internal locus of control. Thus pre-service teachers should be encouraged to have internal locus of control in order to provide students with critical thinking dispositions in further studies especially in the critical pedagogy applications.

\section{References}

Abouserie, R. (1994). Sources and levels of stress in relation to locus of control and self-esteem in university students. Educational Psychology, 14(3), 323-329. http://dx.doi.org/10.1080/0144341940140306

Abrami, P., Bernard, R., Borokhovski, E., Wade, A., Surkes, M., Tamim, R., \& Zhang, D. (2008). Instructional interventions affecting critical thinking skills and dispositions: A stage 1 meta-analysis. Review of Educational Research, 78(4), 1102-1134. http://dx.doi.org/10.3102/0034654308326084

Akdere, N. (2012). Turkish pre-service teachers' critical thinking levels, attitudes and self-efficacy beliefs in teaching for critical thinking. $\mathrm{PhD}$ thesis. Middle East Technical University, Ankara. 
Akin, A., Hamedoğlu, M. A., Sariçam, H., Akin, U., İlbay, A. B., Civan, S., \& Demir, T. (2013). The validity and reliability of the Turkish version of the Critical Thinking Disposition Scale. Paper presented at the 2nd ICCLS 2013, December, 17-19, Ankara, Turkey.

Bahadir, Z., Cartel, Z., \& Turan, B. (2014). The correlation between critical thinking disposition and internal-external locus of control of candidate students who participated in special talent examination in School of Physical Education and Sports Ege University. Science, Movement and Health, 14(2), 332-337.

Bakır, S. (2015). Critical thinking dispositions of pre-service teachers. Educational Research and Reviews, 10(2), $225-233$.

Bessick, S. C. (2008). Improved critical thinking skills as a result of direct instruction and their relationship to academic achievement. D.Ed. Thesis. Indiana University of Pennsylvania, Indiana.

Bloom, B. (1976). Human characteristics and school learning. New York: McGraw-Hill.

Bostic, M. N. (2010). Locus of control and academic achievement among first-generation and second-generation college students. Master thesis of Arts. Tennessee Technological University, Cookeville.

Braa, D., \& Callero, P. (2006). Critical pedagogy and classroom praxis. Teaching Sociology, 34(4), 357-369. http://dx.doi.org/10.1177/0092055X0603400403

Buluş, M. (2011). Goal orientations, locus of control and academic achievement in prospective teachers: An individual differences perspective. Educational Sciences: Theory \& Practice, 11(2), 540-546.

Carden, R., Bryant, C., \& Moss, R. (2004). Locus of control, test anxiety, academic procrastination, and achievement among College Students. Psychological Reports, 95, 581-582. http://dx.doi.org/10.2466/pr0.95.2.581-582

Carrillo, M. J. C., \& Benítez, M. L. D. M. (2004). Educational background, modes of discourse and argumentation: Comparing women and men. Argumentation, 18, 403-426. http://dx.doi.org/10.1007/s10503-004-4906-1

Cheung, C. K., Rudowic, E., Kwan, A. S. F., Lang, G., \& Yue, X. D. (2001). Critical thinking among university students: Does the family background matter?. College Student Journal, 35(4), 577-598.

Cirık, İ., Çolak, E., \& Kaya, D. (2015). Constructivist learning environments: The teachers' and students' perspectives. International Journal on New Trends in Education and Their Implications, 6(2), 30-44.

Cohen, M. (1993). Making critical thinking a classroom reality. Political Science and Politics, 26(2), $241-244$. http://dx.doi.org/10.1017/S1049096500037872

Çakmak, G. H. (2010). Evaluation of prospective primary and pre-school teachers' critical thinking level. Education and Science, 35(157), 3-14.

Çırakoğlu, O. C. (2006). Role of locus of control and critical thinking in handling dissatisfactions in romantic relationships of university students. $\mathrm{PhD}$ thesis. Middle East Technical University, Ankara.

Çırakoğlu, O. C., \& Tezer, E. (2010). The predictive role of locus of control and critical thinking on reactions to relationship dissatisfactions of university students. Turkish Psychological Articles, 13(26), 42-46.

Dabbagh, N. (2007). The online learner: Characteristics and pedagogical implications. Contemporary Issues in Technology and Teacher Education [Online serial], $7(3)$. Available: http://www.citejournal.org/vol7/iss3/general/article1.cfm

Dağ, İ. (2002). Kontrol Odağı Ölçeği (KOÖ): Ölçek geliştirme, güvenirlik ve geçerlik çalışması. (Locus of Control Scale: Scale development, reliability and validity study). Türk Psikoloji Dergisi (Turkish Journal of Psychology), 17(49), 77-90.

Dağ, İ. (1990). Kontrol odă̆l, stresle başa çıkma stratejileri ve psikolojik belirti gösterme ilişkileri. PhD thesis. Hacettepe University, Ankara.

Dam, G., \& Volman, M. (2004). Critical thinking as a citizenship competence: Teaching strategies. Learning and Instruction, 14, 359-379. http://dx.doi.org/10.1016/j.learninstruc.2004.01.005

Darshani, R. K. N. D. (2014). A review of personality types and locus of control as moderators of stress and conflict management. International Journal of Scientific and Research Publications, 4(2), 1-8.

Doğanay, A., Taş, M. A., \& Erden, Ş. (2007). Assessing university students; critical thinking skills in the context of a current controversial issue. Educational Administration: Theory and Practice, 52, 511-546.

Dunn, K. E., Rakes, G. C., \&. Rakes, T. A. (2014). Influence of academic self-regulation, critical thinking, and age on online graduate students' academic help-seeking. Distance Education, 35(1), 75-89.

http://dx.doi.org/10.1080/01587919.2014.891426 
Elder, L., \& Paul, R. (2008). Critical thinking: Strategies for improving student learning. Journal of Developmental Education, 32(1), 32-34.

Elliot, B. M. (1999). The influence of an interdisciplinarty course on critical thinking skills. PhD thesis. University of North Texas, Texas.

Ennis, R. H. (1996). Critical thinking. Upper Saddle River, NJ: Prentice-Hall.

Ennis, R. H. (1987). A taxonomy of critical thinking dispositions and abilities. In J. Baron \& R. Sternberg (Eds.), Teaching thinking skills: Theory and practice (pp. 9-26). New York: W.H. Freeman.

Ewen, L. L. (2001). A longitudinal study of nursing students' self-esteem locus of control anxiety critical thinking and academic achievements. PhD thesis. University of South Florida; Retrieved July 16, 2015, from Dissertations \& Theses: Full Text database. (Publication No. AAT 3041104).

Facione, P. (1990). Critical thinking: A statement of expert consensus for pur poses of educational assessment and instruction [Executive summary]. Retrieved from ERIC database. (ED315423)

Facione, N. C., Facione, P. A., \& Carol, A. S. (1994). Critical thinking disposition as a measure of component clinical judgement: The development of the California Critical Thinking Disposition Inventory. Journal of Nursing Education, 33(8), 345-350.

Faciona, P. A. Faciona, N. C., \& Giancarlo, C. A. (1999). Professional judgment and the disposition toward critical thinking (pp.1-17). California Academic Press.

Facione, P. A., Sanchez, C. A., Facione, N. C., \& Ganien, J. (1995). The disposition toward critical thinking. Journal of General Education, 44(1), 1-25.

Fagbohungbe, O. B., \& Jayeoba, F. I. (2012). Locus of control, gender and entrepreneurial ability. British Journal of Arts and Social Sciences, 11(1), 74-85.

Ferrari, J. R., Parker, J. R., \& Ware, C. B. (1992). Academic procrastination: Personality correlates with Myers-Briggs types, self-efficacy, and academic locus of control. Journal of Social Behavior and Personality, 7, 495-502.

Flor, R. K., Bita, A., Monir, K. C., \& Zohreh, Z. Z. (2013). The effect of teaching critical and creative thinking skills on the locus of control and psychological well-being in adolescents. Procedia - Social and Behavioral Sciences, 82(3), 51-56. http://dx.doi.org/10.1016/j.sbspro.2013.06.223

Gašić-Pavišić, S., Joksimović, S., \& Janjetović, D. (2006). General self-esteem and locus of control of young sportsmen. Zbornik Instituta za Pedagoška Istraživanja, 38(2), 385-400. http://dx.doi.org/10.2298/ZIPI0602385G

Gibby, C. (2013). Critical thinking skills in adult learners. Arecls, 10, 147-176.

Grimes, P., Millea, M., \& Woodruff, T. (2004). Grades: Who is to blame? Student evaluation of teaching and locus of control. Journal of Economic Education, 35(2), 129-147. http://dx.doi.org/10.3200/JECE.35.2.129-147

Ishiyama, J. T., McClure, M., Hart, H., \& Amico, J. (1999). Critical thinking disposition and locus of control as predictors of evaluations of teaching strategies. College Student Journal, 33(2), 269-278.

İslambay, D. (2014). A preliminary analysis of non-material beliefs in Turkish sample: The predictibility of locus of control, system justification, religious/spirttual coping and religiosity. Master thesis. Middle East Technical University, Ankara.

Jenkins, E .K. (1998). The significant role of critical thinking in predicting auditing students' performance. Journal of Education for Business, 73(5), 274-279. http://dx.doi.org/10.1080/08832329809601644

Kaasboll, J. J. (1998). Teaching critical thinking and problem defining skills. Education and Information Technologies, 3, 101-117. http://dx.doi.org/10.1023/A:1009682924511

Kleiber, D. A., \& Hemmer, J. D. (1981). Sex differences in the relationship of locus of control and recreational sport participation. Sex Roles, 7(8), 801-810. http://dx.doi.org/10.1007/BF00287765

Konan, N. (2013). Relationship between locus of control and problem-solving skills of high school administrators. International Journal of Social Sciences and Education, 3(3), 786-794.

Küçükkaragöz, H., Akay, Y., \& Canbulat, T. (2013). Rotter İç- D1ş Kontrol Odağı Ölçeğinin öğretmen adaylarında geçerlik ve güvenirlik çalışması. Akademik Bakış Dergisi, 35. http://www.akademikbakis.org/eskisite/35/06.pdf

Lai, E. R. (2011). Critical thinking: A literature review. Research report. Assessment \& Information group of Pearson. http://images.pearsonassessments.com/images/tmrs/CriticalThinkingReviewFINAL.pdf

Laxman, K. (2010). A conceptual framework mapping the application of information search strategies to sell and ill-structured problem-solving. Computers \& Education, 55(2), 513-526. 
http://dx.doi.org/10.1016/j.compedu.2010.02.014

Leach, B. T. (2011). Critical thinking skills as related to university students gender and academic discipline. Electronic theses and dissertations. Paper 1251. http://dc.etsu.edu/etd/1251

Loghmani, H. (2010). The effect of critical thinking skill teaching on locus of control and cognitive inconsistency. Master`s Thesis. Payame Noor University, Tehran.

Marina, L. M., \& Halpern, D. F. (2011). Pedagogy for developing critical thinking in adolescents: Explicit instruction produces greatest gains. Thinking Skills and Creativity, 6, 1-13. http://dx.doi.org/10.1016/j.tsc.2010.08.002

Marks, L. I. (1998). Deconstructing locus of control: Implications for practitioners. Journal of Counseling \& Development, 76(3), 251-260. http://dx.doi.org/10.1002/j.1556-6676.1998.tb02540.x

Marlowe, A. B., \& Page, L. M. (2005). Creating and sustaining the constructivist classroom. ( $2^{\text {nd }}$ edition). California: Corwin Press.

McLaughlin, S. C., \& Saccuzzo, D. P. (1997). Ethnic and gender differences in locus of control in children referred for gifted programs: The effects of vulnerability factors. Journal for the Education of the Gifted, 20(3), 268-283. http://dx.doi.org/10.1177/016235329702000305

Miller, J. (2005). The impact of locus of control on minority students. Master thesis. University of Wisconsin-Stout, Menomonie.

Morrison, K. (2008). Democratic classrooms: Incorporating student voice and choice in teacher education courses. Retrieved from http://www.newfoundations.com/Morrison.html

Munir, S., \& Sajid, M. (2010). Examining locus of control (loc) as a determinant of organizational commitment among University Professors in Pakistan. Journal of Business Studies Quarterly, 1(3), 78-93.

Novicki, S. (1973, August). Predicting academic achievement of females from a locus of control orientation: some problems and some solutions. Paper presented at the Annual Convention of the American Psychological Association 81st, Montreal, Canada.

O'Hare, L., \& McGuinness, C. (2009). Measuring critical thinking, intelligence, and academic performance in psychology undergraduates. The Irish Journal of Psychology, 30(3-4), 123-131. http://dx.doi.org/10.1080/03033910.2009.10446304

Özen Kutanis, R., Mesci, M., \& Övdür, Z. (2011).The effects of locus of control on learning performance: A case of an academic organization. Journal of Economic and Social Studies, 1(2), 113-136. http://dx.doi.org/10.14706/JECOSS11125

Paul, R., \& Elder, L. (2012). Critical thinking: Tools for taking charge of your learning and your life ( $3^{\text {rd }}$ edition). Upper Saddle River, NJ : Prentice Hall .

Richmond, J. E. D. (2007). Bringing critical thinking to the education of developing country professionals. International Education Journal, 8(1), 1-29.

Rodriguez, G. (2000). Demographics and disposition as predictors of the application of critical thinking skills in nursing practice. Dissertation Abstracts International, 62(1), (UMI No. AAT 3002095).

Rose, R. J., Hall, C. W., Bolen, L. M. \& Webster, R. E. (1996). Locus of control and college students' approaches to learning. Psychological Reports, 79, 163-171. http://dx.doi.org/10.2466/pr0.1996.79.1.163

Rotter, J. B. (1966). Generalized Expectancies for Internal and External Control of Reinforcement. Psychological Monographs, 80, 1-28. http://dx.doi.org/10.1037/h0092976

Rudd, R., Baker, M., \& Hoover, T. (2000). Undergraduate agricultural student learning styles and critical thinking abilities: Is there a relationship? Journal of Agricultural Education, 41(3), 2-12.

Ruff, L. G. (2005). The development of critical thinking skills and dispositions in first-year college students: Infusing critical thinking instruction into a first-year transitions course. Master thesis. University of Maryland, College Park.

Saracaloğlu, A. S., \& Yılmaz, S. (2011). An investigation of prospective teachers' critical thinking attitudes and locus of control. Elementary Education Online, 10(2), 468-478.

Sariçam, H. (2015). Academic locus of control and motivational persistence: Structural equation modeling. Journal of Educational Sciences Research, 5(1), 79-92. http://dx.doi.org/10.12973/jesr

Sariçam, H. (2014). Psychometric properties and adaptation of the Academic Locus of Control Scale to the Turkish Adolescents. Elementary Education Online, 13(4), 1135-1144. 
Sariçam, H., Duran, A., \& Çardak, M. (2012). The examination of pre-school teacher candidates' academic locus of control levels. Mevlana International Journal of Education (MIJE), 2(2), 67-74.

Schunk, D. H. (2012). Learning theories: An educational perspective (6th Edition). Boston: Pearson Education Inc.

Shah, C. G. (2010). Critical thinking. What it is and why it matters to emerging professionals? Advanced Materials and Processes, 168(5), 66-67.

Shepherd, S., Owen, D., Fitch, T., \& Marshall, J. (2006). Locus of control and academic achievement in high school students. Psychological Reports, 98, 318-322. http://dx.doi.org/10.2466/pr0.98.2.318-322

Sherman, A. C., Higgs, G. E., \& Williams, R. L. (1997). Gender differences in the locus of control construct. Psychology \& Health, 12(2), 239-248. http://dx.doi.org/10.1080/08870449708407402

Slavin, R. E. (2012). Educational psychology: Theory into practice $\left(10^{\text {th }}\right.$ Ed.). Boston: Allyn \& Bacon.

Stocks, A., April, K. A., \& Lynton, N. (2012). Locus of control and subjective well-being - a cross-cultural study. Problems and Perspectives in Management, 10(1), 17-25.

Thompson, C. (2011). Critical thinking across the curriculum: Process over output. International Journal of Humanities and Social Science, 1(9), 1-7.

Thompson, S. D., Martin, L. Richards, L., \& Branson, D. (2003). Assessing critical thinking and problem solving using a web-based curriculum for students. Internet and Higher Education, 6, 185-191. http://dx.doi.org/10.1016/S1096-7516(03)00024-1

Tong, H. (2001). Loneliness depression anxiety and the locus of control. Chinese Journal of Clinical Psychology, 3, 196-197.

Tuncel, İ., \& Bahtiyar, A. (2015). A case study on constructivist learning environment in content knowledge courses in science teaching. Procedia - Social and Behavioral Sciences, 174, 3178- 3185. http://dx.doi.org/10.1016/j.sbspro.2015.01.1059

Tümkaya S., Aybek, B., \& Aldağ, H. (2009). An investigation of university students' critical thinking disposition and perceived problem solving skills. Eurasian Journal of Educational Research, 36, 57-74.

Türker, M. V., \& İnel, M. N. (2012). The effect of locus of control orientation on perceived individual innovativeness: An empirical research in Turkey. Procedia - Social and Behavioral Sciences, 58, 879- 888. http://dx.doi.org/10.1016/j.sbspro.2012.09.1066

Varga, R. (2011). The importance of enhancing critical thinking skill of pre-service teachers. Training and Practice, 9(1-2), 97-106.

Vierra, R. W. (2014). Critical thinking: Assessing the relationship with academic achievement and demographic factors. D.Ed. thesis. University of Minnesota, Minneapolis and St. Paul.

Walker, S. E. (2004). Active learning strategies to promote critical thinking. Journal of Athletic Training, 38(3), 263-267.

Winch, C. (2006). Education, autonomy and critical thinking. London, UK: Routledge.

Wood, A. M., Saylor, C., \& Cohen, J. (2009). Locus of control and academic success among ethnically diverse baccalaureate nursing students. Nursing Education Perspectives, 30(5), 290-294.

World Health Organization. (2001). Skills for health skills-based health education including life skills: An important component of a Child-Friendly/Health-Promoting School. Information Series on School Health. Document 9. http://www.who.int/school_youth_health/media/en/sch_skills4health_03.pdf

Zainuddin, R., \& Taluja, H. (1990). Aggression and locus of control among undergraduate students. Journal of Personality and Clinical Studies, 6, 211-215.

Zhang, L. F. (2003). Contributions of thinking styles to critical thinking dispositions. Journal of Psychology, 137(6), 517-543. http://dx.doi.org/10.1080/00223980309600633

Zyngier, D. (2012). Rethinking the thinking on democracy in education: What are educators thinking (and doing) about democracy? Education, 2, 1-21. 